\title{
A Debate on Exercise Addiction Levels of Sport Sciences Students
}

\section{Firat Uzun, Firat Akcan*, Zarife Pancar, Haci Murat Sahin}

Department of Sport Sciences, Gaziantep Üniversitesi, Gaziantep, Turkey

Study Area: Gaziantep, Turkey

Coordinates: $37^{\circ} 04^{\prime} \mathrm{N} ; 37^{\circ} 23^{\prime} \mathrm{E}$

Keywords: Excersice, Sports, Physical Fitness

\section{Abstract}

Exercise addiction levels among Gaziantep University Faculty of Sport Sciences students in terms of various variables were studied in which 320 athletes (138 females, 182 males) actively engaged in sports for at least 1 year were included. In addition to the questionnaire in which demographic characteristics of the participants were questioned, Exercise Dependence Scale-21 was used. When looking at the addiction levels of the athletes who participated in the study; $28.8 \%$ of the students are asymptomatic, $64.7 \%$ are symptomatic and $6.6 \%$ are exercise addicts. Conclusively, exercise addiction was not found common among the students, but the vast majority of them were at risk. It is thought that informing students about exercise addiction and taking necessary precautions will be beneficial in terms of decreasing the risk of exercise addiction.

Despite the fact that studies worldwide on exercise addiction in Turkey are limited studies in this area. Since there are no more literature studies on exercise addiction and new studies are needed, this research has been planned and carried out. The data obtained from this study is very important in terms of leading those who will work on similar subjects.

\section{Material and Method:}

The descriptive method was used as a method in the research. With the personal information form used in the study, the situation between physical activity levels and exercise addiction was tried to be determined. In this study; the relationship between the parameters we took as independent variables such as gender, height, sports age, body mass index, the department attended, and the exercise dependence level parameter, which we took as the dependent variable, was examined.

The study consisted of 320 students (182 boys, and 138 girls) who had been studying in Gaziantep University School of Physical Education and Sports (Faculty of Sport Sciences) in the 2019-2020 academic year and did sports regularly for at least one year. The lower age limit of the samplegroup was set as 17 and the upper limit was left open.

Exercise Dependence Scale-21 Questionnaire was used to determine the exercise habits and attitudes of the students. The Exercise Dependence Scale-21 was developed by Hausenblas \& Downs, (2002) of the Exercise Laboratory, Department of Exercise and Sport Sciences, University of cardiovascular system diseases, cancer types, and musculoskeletal disorders (Arabaci \& Cankaya, 2007).

*Corresponding Author:firatakcan@yahoo.com 
Florida, and Daniel Symons Downs, Pennsylvania State University (Hausenblas \& Downs, 2002). The reason we used this scale in our study was created recently. This study aimed to determine exercise dependence in general without relying on a sports branch and to measure exercise dependence in three dimensions a dependent, nondependent symptomatic, and non-dependent asymptomatic. This scale can be applied to those aged 18 and over individually or as a group. The answers are arranged on a 6-point Likert Scale with never (1 point) and always (6 points). The Exercise Addiction Scale-21, which consists of 21 questions, is based on the DSM-IV criteria for substance addiction and provides the following information:

1. Average exercise dependence symptoms scores (points).

2. It distinguishes the following:

Individuals at risk of exerciseaddiction

Non-dependent symptomatic individuals

Non-addicted asymptomatic individuals

3. Identification of the following situations in individuals:

Physiological dependence (tolerance or cessation of exercise syndrome).

No physiological dependence (no tolerance or evidence of cessation of exercise syndrome)

The scale is based on 7 addiction criteria: tolerance, effects of cessation of exercise, intention effect, loss of control, time, reduction of other activities, and continuity. If 3 or more of these criteria (each criterion consists of 3 questions) get an average of 5-6 points, exercise addicts are classified as symptomatic if they get 3-4 points and asymptomatic if they get 1-2 points (Hausenblas \& Downs, 2002). The Turkish validity and reliability study of the Exercise Dependence Scale was conducted by Yeltepe, and the Cronbach alpha coefficient was calculated as 0.97 as a result of the reliability analysis (Yeltepe, 2005).

Body Mass Index Calculation: BMI is defined as the division of an individual's body mass by the square of the neck. In other words, it is the ratio of height square to body weight (BMI $=\mathrm{kg} / \mathrm{mz}$ ). To calculate BMI, bodyweight is converted into kilograms and height into meters (Carmack \& Martens, 1979). The height of the students was measured with a meter with very good sensitivity and $1 \mathrm{~cm}$ precision. The weight measurements of the students were measured with a Fakir scale with a sensitivity of $1 \mathrm{~kg}$. During the measurement, it was ensured that the students both move more comfortably and wear light clothing. During the measurement of the students, their shoes were removed and the head and shoulder alignment was taken into consideration and the body weight $(\mathrm{kg})$ and height $(\mathrm{cm})$ values were recorded on the information form (Heyward \& Stolarczyk, 1996).

In order to examine the effect of independent variables (age, gender, department, sports age, body weight, height) on the level of exercise dependence, which is the dependent variable; It is given by the percentage, frequency, arithmetic mean, and standard deviation scores of the participants with descriptive parameters. Pearson Correlation test was conducted to test the relationship between age, height, body weight, sports age, and exercise dependence level. Since the gender variable contains two categories, the Independent Sample T-Test was used for its effect on exercise dependence level. Finally, since the Departmental independent variable contains more than 2 categories, the One Way ANOVA Test was used, and the LSD test was used as a Post Hoc test in order to understand which groups the significance is in.

\section{Results:}

However, the gender-wise data on the distribution of the 320 volunteers participating in the study was- 138 participants were women $(43.1 \%)$ and the rest 182 of them were male $(56.9 \%)$.

Table-1: Descriptive parameters of the volunteers participating in the study

\begin{tabular}{llll}
\hline Parameters & $\mathrm{N}$ & Mean & Std. Dev. \\
\hline Age $($ years $)$ & 320 & $\mathbf{2 2 . 2 2}$ & $\mathbf{2 . 4 0}$ \\
Height $(\mathrm{cm})$ & 320 & 172.39 & 7.984 \\
Body Weight $(\mathrm{kg})$ & 320 & 66.23 & 11.054 \\
Sports age (years) & 320 & 9.20 & 4.44 \\
\hline
\end{tabular}

Table-2: The volunteers participating in the study as per the departments they studied

\begin{tabular}{llc}
\hline Departmant & F & $\%$ \\
\hline Sports Management 1. Education & 79 & 24.7 \\
Coaching 1. Education & 81 & 25.3 \\
Physical Education Teacher & 80 & 25 \\
Sports Management 2. Education & 40 & 12.5 \\
Coaching 2. Education & 40 & 12.5 \\
Total & 320 & 100 \\
\hline
\end{tabular}

Table-3: Percentage and frequency values regarding exercise dependence levels of the volunteers participating in the study.

\begin{tabular}{llllll}
\hline Level & $\mathrm{F}$ & $\%$ & Level & $\mathrm{F}$ & $\%$ \\
\hline Asymptomatic & 92 & 28.8 & Symptomatic & 207 & 64.7 \\
Dependent & $\mathbf{2 1}$ & 6.6 & Total & 320 & 100 \\
\hline
\end{tabular}

Table-4: Analysis of the relationship between the age. sports age. height and body weight of the volunteers participating in the study and their exercise dependence levels (Pearson Correlation)

\begin{tabular}{|c|c|c|c|c|c|c|}
\hline \multicolumn{2}{|l|}{ Variable } & \multirow{2}{*}{$\begin{array}{l}\begin{array}{l}\text { Age } \\
(\mathrm{yr})\end{array} \\
-0.136\end{array}$} & \multirow{2}{*}{$\begin{array}{l}\text { Height } \\
(\mathrm{cm})\end{array}$} & \multirow{2}{*}{$\begin{array}{l}\text { Sports } \\
\text { age } \\
-0.009\end{array}$} & \multirow{2}{*}{$\begin{array}{l}\text { VKI } \\
0.022\end{array}$} & \multirow{2}{*}{$\begin{array}{l}\begin{array}{l}\mathrm{BM} \\
(\mathrm{kg})\end{array} \\
0.034\end{array}$} \\
\hline Diagnostic & $\mathrm{r}$ & & & & & \\
\hline $\mathrm{p}<0.05$ & $\mathrm{p}$ & 0.015 & 0.613 & 0.873 & 0.699 & 0.542 \\
\hline & $\mathrm{N}$ & 320 & 320 & 320 & 320 & 320 \\
\hline
\end{tabular}

Pearson Correlation test was performed to analyze the relationship between the age, sports age, height and bodyweight of the volunteers participating in the study, and the exercise dependence levels of body mass index. Accordingly, while there is a very low negative correlation between the age parameter and exercise dependence levels. no statistically significant difference was found between the other parameters and exercise dependence levels $(\mathrm{p}<0.05)$. 
TECHNOSCIENCE ARTICLE

Table-5: T-test conducted to understand whether the exercise dependence levels of the volunteers participating in the study have changed in terms of the gender variable.

\begin{tabular}{lllll}
\hline Gender & $\mathrm{N}$ & Mean & Std. Dev. & $\mathrm{p}$ \\
\hline Woman & 138 & 1.75 & 0.528 & 0.867 \\
Male & 182 & 1.80 & 0.570 & \\
\hline
\end{tabular}

Table-6: Anova test results to know the exercise dependence

levels of the volunteers participating in the study change in terms of the department variable

\begin{tabular}{lllll}
\hline Departmant & N & Mean & Std. Dev. & p \\
\hline Sports Management & 79 & 1.66 & 0.528 & $0.07^{*}$ \\
Coaching & 81 & 1.90 & 0.539 & \\
Physical Education Teacher & 80 & 1.81 & 0.553 & \\
Sports Management 2. Education & 40 & 1.73 & 0.640 & \\
Coaching 2. Education & 40 & 1.75 & 0.494 & \\
Total & 320 & 1.78 & 0552 & \\
\hline
\end{tabular}

As a result of the Anova test conducted to understand whether the exercise dependence levels of the volunteers participating in the study changed in terms of the department variable, it was concluded that the department variable did not make any statistically significant difference on the exercise dependencelevel $(\mathrm{p}<0.05)$.

\section{Discussion and Conclusion:}

In this study, the reason why the participants were chosen from among the students who have higher education in sports is that addiction is a condition acquired at an early age and it is thought that the exercise addiction of the students who were intertwined with exercise throughout their education and training life may be high. Therefore, this study was carried out with 320 students, who were studying in 3 different departments and 5 different classes for 4 years with an average age of $22.22 \pm 2.40$ years, and who accepted to participate in the study who filled the questionnaire form. When the findings of this study on exercise addiction were examined, a very low level of negative significant relationship was found between the variables of gender, age, height, sports age, body weights, body mass index, and department variables and exercise dependence, only between age and exercise dependence level. There was no statistically significant relationship between other parameters and exercise dependence level ( $\mathrm{p}$ $<0.05)$. However, it is thought that the majority of the participants were symptomatic $(64.7 \%)$, therefore they werecandidates for exercise addiction.

It is thought that the training received in the Faculty of Sports Sciences allows the participants to consciously exercise. Therefore, this situation can be considered as a factor preventing participants from becoming exercise addicts. Sadiq (2018) studied exercise addiction levels in Taekwondo, Kickbox and Muaythai athletes in terms of few variables, such as age, height, gender, education level, sports age, etc. and found no statistically significant difference between the levels of exercise dependence and exercisedependence.
Ambient Science, 2021: Vol. 08(Sp1); 49-52 DOI:10.21276/ambi.2021.08.sp1.ta05

Vardar et al., (2012), reported that 14 (12\%) of 115 adults had exercise dependence, $71(62 \%)$ were not dependent but could be, and $30(26 \%)$ were not addicted. As a result of this study $6.6 \%(n=21)$ of the students were exercise addicts, $64.7 \%(n=207)$ of the students were candidates for exercise addiction, and $28.8 \%(n=92)$ of the students were not exercising addicts. Some studies shown variability in exercise dependence according to the gender variable. Gün (2018) found $13.2 \%$ of male students, $15.8 \%$ of female students, and $14.1 \%$, in general, were addicted to exercise, and $65.8 \%$ of male students and $52 \%$ of female students. 5 of them and $58.7 \%$, in general, have determined that they are dependent candidates. Although addiction levels are low, it is observed that female and male students are highly likely to be dependent. Lichtenstein et al., (2014) claim that there was no significant difference between the exercise dependencies of individuals who do team sports and gym sports (Lichtenstein et al., 2014).

As a result of another study it was reported that the physical fitness of the students studying teaching and coaching was at a high level and that of the students of the sports management department. Similarly, as a result of the study, it was observed that the class, department, and branches of the participants had no effect on exercise addiction (Borazan, 2015). When this study was evaluated in general, it was concluded that very few of the students studying at the Faculty of Sports Sciences were exercise addicts, other variables except age did not affect exercise dependence, and there was no significant relationship with body mass indexes according to the exercise addiction status of the students. As any behavior, especially in young people, progresses, it becomes addictive and causes other uncontrollable behaviors to occur. In order to prevent this situation, it is necessary to eliminate or eliminate addiction candidates or addicts from these behaviors by organizing different activities in quality and quantity to meet the needs and demands of individuals. This would only be possible with activities with a large variety of physical activity (Costa et al., 2013; Bamber et al., 2003; Hailey \& Bailer, 1982; Blaydon et al., 2002; Canpolat et al., 2018).

Activities should be planned in accordance with the needs of the participants, otherwise, it was thought that the current situation will continue. Since exercise addiction should not be distinguished from other addiction types, it is recommended to investigate the subject not only on students studying in education programs on this subject but also on individuals from different segments and different professions. In addition, in line with the findings obtained as a result of this research, it is thought that it may be beneficial to conduct studies on the subject of individuals of different age groups. Similarly, it is thought that applying the study to the students of the Faculty of Sports Sciences in different provinces may be beneficial in understanding the general picture. 


\section{References:}

Arabaci, R. \& Çankaya, C. (2007): Beden egitimi ögretmenlerinin fiziksel aktivite düzeylerinin arastirilmasi. Uludag Üniversitesi Egitim Fakültesi Dergisi, 20(1):1-15. 20(1):1-15.

Bamber, D.J., Cockeril, I.M., Rodgers, S. \& Carroll, D. (2003): Diagnositc criteria for exercise dependence in women. $\underline{B r}$. J. Sport. Med.,37(5):393-400

Blaydon, M.B., Koenraad, J.L. \& Kerr, J.H. (2002): Metamotivational characteristics of eating disordered and exercise dependent triathletes: An application of reversal theory. Psychol. Sports Exer., 3(3):223-236.

Borazan, H. (2015): Beden eðitimi ve spor yüksek okulunda ögrenim gören bayan ögrencilerin fiziksel aktivite düzeyleri, Yüksek Lisans Tezi, Nigde Üniversitesi Nigde.

Canpolat, B., Aribas, N. \& Ilkim, M. (2018): What is the Perception of Democracy in the Around Disadvantaged Individuals Playing Sports? In: Academic Approaches in Sports Sciences. Pub by: Akademisyen Press, Ankara.

Carmack, M.A. \& Martens, R. (1979): Measuring commitment to running: A surveyof runners' attitudes and mental states. $J$ Sport. Psychol., 1(1):25-42.

Casperen, C.J., Powell, K.E. \& Christensen, G.M. (1985): Physical activity, exercise and physical fitness: Definitions and distinctions for health-related research. Pub. Health Rep., 100(2):126-131

Cerin, C. \& Leslie, E. (2008): How socio-economic status contributes to participation in leisure-time physical activity. Soc. Sci. Med., 66(12):2596-2609.

Costa, S., Hausenblas, A.H., Oliva, P., Cuzzocrea, F. \& Larcan, R. (2013): The role of age, gender, mood states and exercise frequency on exercise dependence. J. Beh. Addict., 2(4):216-223.

Gün, A. (2018): Beden Egitimi ve Spor YüksekokuluÖgrencilerinin Egzersiz Bagimlilik Durumlarina Göre Fiziksel Aktivite ve Vücut Kitle Indekslerinin Karsilastirilmasi. Yüksek Lisans Tezi. Erzincan Binali Yildirim Üniversitesi Saglik Bilimleri Enstütüsü, Erzincan.

Hailey, B.J. \& Bailey, L.A. (1982): Negative addiction in runners: A quantitative approach. J. Sport Behav., 5:150-154.
Hausenblas, H.A. \& Downs, D.S. (2002): Exercise dependence: A systematic review. Psychol. Sport Exer., 3(2):89-123.

Heyward, V.H. \& Stolarczyk, L.M. (1996): Applied body composition assessment.Champaign. IL;Hum. Kin., (1):1-55.

Lichtenstein, M.B., Larsen, K.S., Christiansen, E., Støving, K.R. \& Bredahl, T.V.G. (2014): Exercise addiction in team sport and individual sport: Prevalences and validation of the exercise addiction inventory. Addict. Res. Theory, 22(5):431-437.

Miller, D.J., Fredsoon, P.S. \& Kline, G.M. (1994): Comparison of aktivity levels using the caltrac accelerometer and five ouestionnaires. Med. Sci. Sport. Exer., 26(3):376-382.

Sadiq, B.J. (2018): Investigation of the exercise dependence of Athlets' KickBoxing, Taekwondo and Muay Thai. Fýrat University, Institute of Health Sciences Department of Physýcal Education and Sports Master Thesis.

Seferoglu, S.S. \& Yildiz, H. (2013): Dijital çagin çocuklari: Ilkögretim ögrencilerinin Facebook kullanimlari ve internet bagimliliklari üzerine bir arastirma, Iletisim ve Diplomasi Dergisi, 2, Çocuk ve Medya Özel Sayisi, (s. 31-48).

Smith, D. \& Hale, B. (2005): Exercise-dependence in bodybuilders: Antecedents and reliability of measurement. L. Sport. Med. Phys. Fit., 45:401-408.

Vardar, E., Vardar, S.A., Toksöz, Ý. \& Süt, N. (2012): Egzersiz bVardar, bagimliligi ve psikopatolojik özelliklerinin degerlendirilmesi. Düsünen Adam Psikiyatri ve Nörolojik Bilimler Dergisi, 25:51-57.

Yeltepe, H. (2005): Egzersiz bagimliliginin tanimlanmasi Ve "Egzersiz Bagimliligi Ölçegi-21 in geçerlilik ve güvenilirlik çalismasinin yapilmasi. Istanbul: Yayinlanmamis Yüksek Lisans Tezi, Saglik Bilimleri Enstitüsü, Marmara Üniversitesi.

Young, K.S. (1999): Internet addiction: Evaluation and treatment. Stu. Br. Med.J. 7:351-352.

Zorba, E., Ziyagil, M., Çolak, H., Kalkavan, A., Kolukisa, S., Torun, K. \& Özdag, S. (1995): 12-15 yas grubu futbolcularin antropometrik ve fiziksel uygunluk degerlerinin sedanter grupla karsilastirilmasi. Bilim ve Teknoloji Futbol Dergisi, 40(3):17-22. 